\title{
Contingency research in operations management practices
}

\author{
Rui Sousa ${ }^{\mathrm{a}, *}$, Christopher A. Voss ${ }^{\mathrm{b}, 1}$ \\ Catholic University of Portugal (Porto), Universidade Catolica Portuguesa, Rua Diogo B́otelho 1327, 4069-005 Porto, Portugal \\ b London Business School, Sussex Place, Regent's Park, London NW1 4SA, United Kingdom \\ Keywords: \\ Contingency research \\ Best practice \\ Contingency theory
}

\section{A B S T R A C T}

\begin{abstract}
As operations management (OM) best practices have become mature, research on practices has begun to shift its interest from the justification of the value of those practices to the understanding of the contextual conditions under which they are effective-OM practice contingency research (OM PCR). This article sets out to examine and critique the current state of OM PCR. We review OM PCR studies through the lens of the major theoretical view on contingencies, contingency theory, along a number of relevant dimensions: contingency variables, performance variables, measurement, research design and employed form of fit. In this process, we put forward a number of tasks that need to be accomplished in order to move OM PCR forward and develop more solid conceptual foundations in which to anchor rigorous research in this area. Finally, we reflect on the theoretical arguments that underlie OM PCR (which are based on the contingency approach) and identify its limitations in fully explaining the currently observed patterns of use of OM practices and associated performance outcomes. As a result, we propose that in order to increase our understanding of these patterns, OM scholars need to study in more depth the process of selection of OM best practices by organizations. Accordingly, we put forward a framework to underpin such research integrating contingency theory and other theoretical perspectives.
\end{abstract}

\section{Introduction}

In the last three decades, operations management (OM) has seen the proliferation of a plethora of new management practices encapsulated under themes such as total quality management and lean production. These new practices have acquired a strong prescriptive stance and have often been advocated as universally applicable to organizations and organizations activities. This trend is part of the emergence of a new paradigm in OM based on the assumption that the adoption of best (world class) practice in a wide range of areas leads to superior performance-the best practice paradigm (Voss, 1995). This paradigm focuses on the continuous development of

\footnotetext{
* Corresponding author. Tel.: +35122 6196229; fax: +351226196291. E-mail addresses: rsousa@porto.ucp.pt (R. Sousa), cvoss@london.edu (C.A. Voss).

${ }^{1}$ Tel.: +44 207000 7000; fax: +44 2070007001 .
}

best practice on all areas within a company and is supported by research showing links between the adoption of best practice and improved performance (e.g., Cua et al., 2001; Flynn et al., 1995; Fullerton et al., 2003; Hendricks and Singhal, 1997; Jayaram and Droge, 1999; McKone and Schroeder, 2001).

As these emergent or promising practices have matured and learning about them has taken place, doubts have been raised as to their universal validity. The proclamation of the universal value of these practices has frequently stemmed from anecdotal case studies of "excellent" or "world class manufacturing" firms, which tend to be large and operate in global, high-tech, and/or highly competitive and dynamic industries. These also tend to be the type of companies that make up the samples used in the practiceperformance empirical studies. Furthermore, these studies are typically survey-based and thus frequently miss out on the contextual richness of the intervening firms and the eventual effects that firm context may have on the practice-performance relationships. In addition, several 
practice-performance studies have found that some practices did not have a significant impact on performance (e.g., Dow et al., 1999; Powell, 1995) and it has been suggested that this may be due to these practices being context dependent (Dow et al., 1999; Ketokivi and Schroeder, 2004b; Sousa and Voss, 2002).

Simultaneously, the OM practitioner literature abounds with reports of problems in implementing best practices (e.g., Bowman, 1996; Dooyoung et al., 1998; Maddow, 1995). Although proponents of the universal view of OM best practices would argue that implementation difficulties are part of moving the organization towards "excellence" or "world class status", an alternative explanation is that these difficulties result from too great a mismatch between the proposed form of best practice and the particular organizational context (Sousa and Voss, 2001).

Against this background, research in maturing OM best practices has recently began to see a shift in interest from the justification of the value of those practices to the understanding of the contextual conditions under which they are effective. Such research is typically anchored on a contingency approach and examines relationships between contextual variables, the use of practices and the associated performance outcomes. We call this body of research OM practice contingency research (OM PCR). Despite the growing importance of this body of research, it is still built on limited conceptual foundations, lacking a unifying research framework and common terminology. For example, many studies, although being clearly contingency studies, do not position themselves as such. In this connection, the main objective of this paper is to examine and critique the current state of OM PCR. In this process, our aim is to: (i) contribute to a better definition of this body of research as an area of study in OM; (ii) characterize and synthesize research to date and identify its limitations; and (iii) identify a number of tasks that future research should undertake in order to provide more solid conceptual foundations on which to anchor rigorous research in this area.

In this article, we take the perspective that the OM field is strongly based on a contingency paradigm. In this context, OM PCR may be seen as the application of the contingency approach to the study of OM best practices, which have emerged from a "universalistic" paradigm. Given the limited theoretical foundations of OM PCR, we believe that it can benefit from insights from the major theoretical view on contingencies, namely, contingency theory (CT) (e.g., Lawrence and Lorsch, 1967; Thompson, 1967; Woodward, 1958). Although CT has been applied to other areas of OM (primarily, manufacturing strategy), little application of CT has taken place in the study of OM practices. Therefore, we set out to review OM PCR against the backdrop of CT.

The article is organized as follows. In Section 2, we propose CT as a useful theoretical lens through which to review OM PCR. In Section 3, we put forward a working definition of OM PCR for the purposes of our study, anchored on CT, and delimit the scope of our review. In Sections 4-6 we review and critique OM PCR along three main axes: research variables and measurement (contingency variables, performance variables and measurement issues), research design and employed form of fit. In this process, we put forward a number of tasks that need to be accomplished in order to move OM PCR forward. In Section 7, we reflect on the theoretical arguments that underlie OM PCR (which are based on the contingency approach) and identify its limitations in fully explaining the currently observed patterns of use of OM practices and associated performance outcomes. As a result, we propose that in order to increase our understanding of these patterns, OM scholars need to study in more depth the process of selection of OM best practices by organizations. Accordingly, we put forward a framework to underpin such research integrating contingency theory and other theoretical perspectives. Finally, a summarizing conclusion is provided.

The article focuses primarily on manufacturing operations given that mature OM best practices - the primary object of OM PCR - is at present more prevalent in this type of operation. In addition, it focuses primarily on the socalled "world class" (Flynn et al., 1999; Hayes and Wheelwright, 1984) or "innovative" (Ketokivi and Schroeder, 2004b) manufacturing practices. These are generally practices that emerge within the best practice paradigm and typically follow a cycle of introduction, experimentation, maturity (generally established merits) and understanding of contingencies, as discussed above. Even though many of these practices have a cross-functional nature (e.g., quality management practices) they are generally considered under the aegis of OM. For simplicity, we will call them "OM practices".

\section{Contingency theory and its relevance to OM practice contigency research}

In recent years, there has been a growing consensus in the OM field about the benefits of drawing insights from major theories in other fields such as economics, management and organization theory (Amundson, 1998). This trend is linked to the realization that many OM problems have a cross-disciplinary nature and has led to the broadening of the scope of the OM field and the desirability of conducting interdisciplinary research (e.g., Buhman et al., 2005; Handfield, 2006).

$\mathrm{CT}$ is a major theoretical lens used to view organizations. In its most rudimentary form, this theory holds that organizations adapt their structures in order to maintain fit with changing contextual factors, so as to attain high performance (Donaldson, 2001). Theoretical and practical contributions of this approach are achieved by (i) identifying important contingency variables that distinguish between contexts; (ii) grouping different contexts based on these contingency variables; and (iii) determining the most effective internal organization designs or responses in each major group.

CT has yielded many insights and has received substantial empirical support (Donaldson, 2001). Many of its principles have permeated other fields of study, including OM. Seminal work in CT (e.g., Lawrence and Lorsch, 1967; Thompson, 1967; Woodward, 1958) was the precursor of major OM contingency approaches such as Skinner's $(1969,1974)$ notions of fit between the production system and the priorities of the organization (St. John 
Table 1

Academic studies directly addressing contingency factors affecting OM best practice in manufacturing operations

\begin{tabular}{|c|c|c|c|c|c|c|c|c|}
\hline $\begin{array}{l}\text { Contingency } \\
\text { factor }\end{array}$ & $\begin{array}{l}\text { Set of OM } \\
\text { best practices }\end{array}$ & Studies & $\begin{array}{l}\text { Main contextual } \\
\text { variables }\end{array}$ & $\begin{array}{l}\text { Performance } \\
\text { variables }\end{array}$ & $\begin{array}{l}\text { Research } \\
\text { stance }\end{array}$ & $\begin{array}{l}\text { Research } \\
\text { design }\end{array}$ & $\begin{array}{l}\text { Existence of } \\
\text { contingency } \\
\text { effects/ } \\
\text { empirical } \\
\text { component }\end{array}$ & $\begin{array}{l}\text { Form } \\
\text { of fit } \\
\text { (b) }\end{array}$ \\
\hline \multirow{12}{*}{$\begin{array}{l}\text { National } \\
\text { context and } \\
\text { culture }\end{array}$} & \multirow{4}{*}{$\begin{array}{l}\text { General } \\
\text { manufacturing } \\
\text { best practices }\end{array}$} & $\begin{array}{l}\text { Voss and } \\
\text { Blackmon (1998) }\end{array}$ & $\begin{array}{l}\text { Strategic time orientation } \\
\text { (short-term vs. long-term) }\end{array}$ & - & $\begin{array}{l}\text { Exploratory } \\
\text { study (a) }\end{array}$ & Non-inferential & $\mathrm{Y} / \mathrm{Y}$ & S \\
\hline & & $\begin{array}{l}\text { Voss and } \\
\text { Blackmon (1996) }\end{array}$ & $\begin{array}{l}\text { Parent country and } \\
\text { country of location }\end{array}$ & - & $\begin{array}{l}\text { Development and test of } \\
\text { propositions specifying } \\
\text { the existence of differences } \\
\text { across contexts in the } \\
\text { use of practices }\end{array}$ & $\begin{array}{l}\text { Inferential } \\
\text { detailed }\end{array}$ & $\mathrm{Y} / \mathrm{Y}$ & S \\
\hline & & $\begin{array}{l}\text { Vastag and } \\
\text { Whybark (1991) }\end{array}$ & Country of location & - & Exploratory study (a) & Non-inferential & $\mathrm{Y} / \mathrm{Y}$ & S \\
\hline & & Oliver et al. (1996) & Country of location & - & Exploratory study (a) & Non-inferential & $\mathrm{Y} / \mathrm{Y}$ & $\mathrm{s}$ \\
\hline & \multirow[t]{6}{*}{$\begin{array}{l}\text { Quality } \\
\text { management }\end{array}$} & $\begin{array}{l}\text { Ebrahimpour } \\
\text { and Cullen (1993) }\end{array}$ & Parent country & - & $\begin{array}{l}\text { Development and test of } \\
\text { hypotheses specifying the } \\
\text { existence of differences } \\
\text { across contexts in the } \\
\text { use of practices }\end{array}$ & $\begin{array}{l}\text { Inferential } \\
\text { aggregate }\end{array}$ & $\mathrm{Y} / \mathrm{Y}$ & S \\
\hline & & Sila (2007) & Parent country & $\begin{array}{l}\text { Human resource results, } \\
\text { customer results, } \\
\text { organizational effectiveness } \\
\text { (operational performance), } \\
\text { financial and market results }\end{array}$ & $\begin{array}{l}\text { Development and test of } \\
\text { propositions specifying the } \\
\text { existence of differences across } \\
\text { contexts in the use of } \\
\text { practices and their relationship } \\
\text { with performance }\end{array}$ & $\begin{array}{l}\text { Inferential } \\
\text { aggregate }\end{array}$ & $N / Y$ & I \\
\hline & & $\begin{array}{l}\text { Rungtusanatham } \\
\text { et al. (1998) }\end{array}$ & Country of location & - & Exploratory study (a) & Non-inferential & $\mathrm{Y} / \mathrm{Y}$ & S \\
\hline & & $\begin{array}{l}\text { Rungtusanatham } \\
\text { et al. (2005) }\end{array}$ & Country of location & - & $\begin{array}{l}\text { Development and test of } \\
\text { propositions specifying the } \\
\text { existence of differences across } \\
\text { contexts in the level of adoption } \\
\text { and pattern of relationships } \\
\text { among the several practices }\end{array}$ & $\begin{array}{l}\text { Inferential } \\
\text { aggregate }\end{array}$ & $\mathrm{Y} / \mathrm{Y}$ & $\mathrm{S}$ \\
\hline & & $\begin{array}{l}\text { Flynn and } \\
\text { Saladin (2006) }\end{array}$ & $\begin{array}{l}\text { Hofstede's dimensions } \\
\text { of national culture }\end{array}$ & - & $\begin{array}{l}\text { Development and test of detailed } \\
\text { hypotheses relating dimensions } \\
\text { of national culture to the degree } \\
\text { of use of practices }\end{array}$ & $\begin{array}{l}\text { Inferential } \\
\text { detailed }\end{array}$ & $\mathrm{Y} / \mathrm{Y}$ & $\mathrm{s}$ \\
\hline & & Mersha (1997) & $\begin{array}{l}\text { Level of country } \\
\text { development }\end{array}$ & - & $\begin{array}{l}\text { Conceptual exploration of } \\
\text { possible reasons for the } \\
\text { existence of contingency effects }\end{array}$ & Non-inferential & $\mathrm{Y} / \mathrm{N}$ & S \\
\hline & $\begin{array}{l}\text { Human } \\
\text { resource } \\
\text { practices }\end{array}$ & $\begin{array}{l}\text { Ahmad and } \\
\text { Schroeder (2003) }\end{array}$ & Country of location & - & $\begin{array}{l}\text { Exploratory analysis of the effect } \\
\text { of context variables on the degree } \\
\text { of use of practices. No contingency } \\
\text { propositions are developed }\end{array}$ & Non-inferential & $\mathrm{Y} / \mathrm{Y}$ & $\mathrm{s}$ \\
\hline & $\begin{array}{l}\text { Total productive } \\
\text { maintenance }\end{array}$ & $\begin{array}{l}\text { McKone } \\
\text { et al. (1999) }\end{array}$ & Parent country & - & $\begin{array}{l}\text { Development and test of } \\
\text { theory-based hypotheses } \\
\text { specifying the existence of } \\
\text { an influence of context } \\
\text { variables on the degree of } \\
\text { use of practices }\end{array}$ & $\begin{array}{l}\text { Inferential } \\
\text { aggregate }\end{array}$ & $\mathrm{Y} / \mathrm{Y}$ & S \\
\hline
\end{tabular}


Table 1 (Continued)

\begin{tabular}{|c|c|c|c|c|c|c|c|c|}
\hline $\begin{array}{l}\text { Contingency } \\
\text { factor }\end{array}$ & $\begin{array}{l}\text { Set of OM } \\
\text { best practices }\end{array}$ & Studies & $\begin{array}{l}\text { Main contextual } \\
\text { variables }\end{array}$ & $\begin{array}{l}\text { Performance } \\
\text { variables }\end{array}$ & $\begin{array}{l}\text { Research } \\
\text { stance }\end{array}$ & $\begin{array}{l}\text { Research } \\
\text { design }\end{array}$ & $\begin{array}{l}\text { Existence of } \\
\text { contingency } \\
\text { effects/ } \\
\text { empirical } \\
\text { component }\end{array}$ & $\begin{array}{l}\text { Form } \\
\text { of fit } \\
\text { (b) }\end{array}$ \\
\hline \multirow[t]{8}{*}{$\begin{array}{l}\text { Firm } \\
\text { size }\end{array}$} & $\begin{array}{l}\text { General } \\
\text { manufacturing } \\
\text { best practices }\end{array}$ & $\begin{array}{l}\text { Cagliano } \\
\text { et al. (2001) }\end{array}$ & Firm size (no. of employees) & $\begin{array}{l}\text { Operational and business } \\
\text { performance (the latter } \\
\text { includes customer and } \\
\text { employee satisfaction, } \\
\text { productivity, market } \\
\text { share and financial } \\
\text { metrics) }\end{array}$ & $\begin{array}{l}\text { Development and test } \\
\text { of hypotheses concerning } \\
\text { the effect of context on the } \\
\text { use of practices and their } \\
\text { impact on performance }\end{array}$ & $\begin{array}{l}\text { Inferential } \\
\text { detailed }\end{array}$ & $\mathrm{Y} / \mathrm{Y}$ & I \\
\hline & & Voss et al. (1998) & Firm size (no. of employees) & - & Exploratory study (a) & Non-inferential & $\mathrm{Y} / \mathrm{Y}$ & $\mathrm{s}$ \\
\hline & \multirow[t]{3}{*}{$\begin{array}{l}\text { Quality } \\
\text { management }\end{array}$} & $\begin{array}{l}\text { Ghobadian and Gallear } \\
(1996,1997)\end{array}$ & Firm size (no. of employees) & - & $\begin{array}{l}\text { Development of theory-based } \\
\text { contingency propositions } \\
\text { examined by case study research }\end{array}$ & $\begin{array}{l}\text { Inferential } \\
\text { detailed }\end{array}$ & $N / Y$ & $\mathrm{~s}$ \\
\hline & & $\begin{array}{l}\text { Ahire and } \\
\text { Golhar (1996) }\end{array}$ & Firm size (no. of employees) & - & $\begin{array}{l}\text { Development and test of } \\
\text { hypotheses specifying the } \\
\text { existence of specific differences } \\
\text { across contexts in the use } \\
\text { of practices }\end{array}$ & $\begin{array}{l}\text { Inferential } \\
\text { detailed }\end{array}$ & $\mathrm{N} / \mathrm{Y}$ & S \\
\hline & & Sila (2007) & Firm size (no. of employees) & See above & $\begin{array}{l}\text { Development and test of } \\
\text { propositions specifying the } \\
\text { existence of differences } \\
\text { across contexts in the use } \\
\text { of practices and their } \\
\text { relationship with } \\
\text { performance }\end{array}$ & $\begin{array}{l}\text { Inferential } \\
\text { aggregate }\end{array}$ & $\mathrm{N} / \mathrm{Y}$ & I \\
\hline & $\begin{array}{l}\text { Lean } \\
\text { manufacturing } \\
\text { (JIT, TQM, } \\
\text { TPM and HRM) }\end{array}$ & $\begin{array}{l}\text { Shah and } \\
\text { Ward (2003) }\end{array}$ & Plant size (no. of employees) & - & $\begin{array}{l}\text { Development and test of } \\
\text { propositions specifying } \\
\text { specific differences } \\
\text { across contexts in the } \\
\text { use of practices }\end{array}$ & $\begin{array}{l}\text { Inferential } \\
\text { detailed }\end{array}$ & $\mathrm{Y} / \mathrm{Y}$ & S \\
\hline & JIT & White (1993) & Firm size (no. of employees) & - & $\begin{array}{l}\text { Descriptive, exploratory } \\
\text { study }\end{array}$ & Non-inferential & $\mathrm{Y} / \mathrm{Y}$ & S \\
\hline & $\begin{array}{l}\text { Total productive } \\
\text { maintenance }\end{array}$ & McKone et al. (1999) & Firm size (no. of employees) & - & $\begin{array}{l}\text { Development and test of } \\
\text { hypotheses specifying the } \\
\text { existence of an influence } \\
\text { of context variables on the } \\
\text { degree of use of practices }\end{array}$ & $\begin{array}{l}\text { Inferential } \\
\text { aggregate }\end{array}$ & $\mathrm{N} / \mathrm{Y}$ & S \\
\hline
\end{tabular}


ate of new product

performance. Performance

grounded explanatory

detailed

impact is implicit in the fact models for the influence of introduction, item

variety, production run sizes and type of production process that the study addresses organizations under fit, context va

use of practices,

complemented with

Das et al. (2000)

Level of international competition Customer satisfaction,

Development and test of

er satisfaction,

detailed hypotheses

performance

specifying differences

across contexts in the use

of practices, the pattern

of their relationships and

Sila (2007)

Scope of operations

See above.

(domestic vs. international)

Development and test of

propositions specifying the

existence of differences

across contexts in the use

of practices and their

relationship with performance

Reed et al. (1996) Environmental uncertainty Business performance

and firm orientation

(revenue and cost)

Sitkin et al. (1994)

(task, product/process and organizational)

World class Hendry (1998) Policy for satisfying customer

manufacturing

practices

JIT/lean

production

Hobbs (1994)

demand (make-to-order

vs. other policies)

Type of production process

(job shop vs. repetitive

production)

White (1993) Type of production process

Funk (1995)

Logistical complexity

Overall firm performance

(not specified)

specifying that the

effectiveness of different

sets of practices depends

on their degree of fit

with context

Case-based recommendations

on how to adapt practices to

a particular context (make-

to-order/job shop production)

(not specified)

James-Moore and $\quad$ Product value,

Gibbons (1997)

volume, complexity

Degree of emphasis on

Human resource Kathuria and

Partovi (1999)

flexibility

Product

Koufteros et al. (2002), Platform strategy,

development

Koufteros et al. (2005) environmental

uncertainty and

equivocality
Overall firm performance

Exploratory study (a)

Development of a proposition

linking the degree of

importance of practices

to context variables

Exploratory study (a)

Managerial performance

Development and test of hypotheses concerning the effect of context on the relationship between the use of practices and

performance

Product quality, product Development and test of propositions specifying the

effect of context variables on

the patterns of relationships

between practices and their

relationship with performance

innovation, firm profitability nferential

detailed

Inferential

$\mathrm{N} / \mathrm{Y}$

aggregate

nferential $\quad \mathrm{Y} / \mathrm{N}$

detailed

Inferential

detailed

Non-inferential $\mathrm{Y} / \mathrm{Y}$

Non-inferential N/Y S

SYS Partial
Non-inferential $\mathrm{Y} / \mathrm{Y}$

Inferential $\mathrm{Y} / \mathrm{N}$

detailed

Non-inferential $\mathrm{Y} / \mathrm{Y}$

Inferentia

$\mathrm{Y} / \mathrm{Y}$

detailed

Inferential

$\mathrm{Y} / \mathrm{Y}$ detailed

SYS Partial


Table 1 (Continued)

\begin{tabular}{|c|c|c|c|c|c|c|c|c|}
\hline $\begin{array}{l}\text { Contingency } \\
\text { factor }\end{array}$ & $\begin{array}{l}\text { Set of OM } \\
\text { best practices }\end{array}$ & Studies & $\begin{array}{l}\text { Main contextual } \\
\text { variables }\end{array}$ & $\begin{array}{l}\text { Performance } \\
\text { variables }\end{array}$ & $\begin{array}{l}\text { Research } \\
\text { stance }\end{array}$ & $\begin{array}{l}\text { Research } \\
\text { design }\end{array}$ & $\begin{array}{l}\text { Existence of } \\
\text { contingency } \\
\text { effects/ } \\
\text { empirical } \\
\text { component }\end{array}$ & $\begin{array}{l}\text { Form } \\
\text { of fit } \\
\text { (b) }\end{array}$ \\
\hline \multirow[t]{7}{*}{$\begin{array}{l}\text { Other organizational } \\
\text { context variables }\end{array}$} & $\begin{array}{l}\text { Quality } \\
\text { management }\end{array}$ & $\begin{array}{l}\text { Benson } \\
\text { et al. (1991) }\end{array}$ & $\begin{array}{l}\text { Several organizational variables } \\
\text { related to the quality context }\end{array}$ & - & $\begin{array}{l}\text { Development and test of } \\
\text { hypotheses specifying the } \\
\text { existence of an influence } \\
\text { of context variables on the } \\
\text { degree of use of practices }\end{array}$ & $\begin{array}{l}\text { Inferential } \\
\text { aggregate }\end{array}$ & $\mathrm{Y} / \mathrm{Y}$ & S \\
\hline & & $\begin{array}{l}\text { Lai and } \\
\text { Cheng (2003) }\end{array}$ & Industry & - & $\begin{array}{l}\text { Development and test of } \\
\text { propositions specifying the } \\
\text { existence of differences across } \\
\text { contexts in the use of practices }\end{array}$ & $\begin{array}{l}\text { Inferential } \\
\text { aggregate }\end{array}$ & $\mathrm{Y} / \mathrm{Y}$ & S \\
\hline & $\begin{array}{l}\text { Employee } \\
\text { involvement }\end{array}$ & Lawler (1988) & $\begin{array}{l}\text { Nature of the work and } \\
\text { technology, values of } \\
\text { participants }\end{array}$ & - & $\begin{array}{l}\text { Deductive development of } \\
\text { propositions specifying the } \\
\text { use of different practices for } \\
\text { different contexts }\end{array}$ & $\begin{array}{l}\text { Inferential } \\
\text { detailed }\end{array}$ & $\mathrm{Y} / \mathrm{N}$ & S \\
\hline & JIT purchasing & $\begin{array}{l}\text { Gonzalez- } \\
\text { Benito (2002) }\end{array}$ & $\begin{array}{l}\text { Volume, specificity, technological } \\
\text { complexity, essentiality, fragility, } \\
\text { variability and economic value } \\
\text { of purchased products }\end{array}$ & - & $\begin{array}{l}\text { Development and test of } \\
\text { hypotheses relating context } \\
\text { variables to the degree } \\
\text { of use of practices }\end{array}$ & $\begin{array}{l}\text { Inferential } \\
\text { detailed }\end{array}$ & $\mathrm{Y} / \mathrm{Y}$ & S \\
\hline & $\begin{array}{l}\text { Lean Manufacturing } \\
\text { (JIT, TQM, TPM } \\
\text { and HRM) }\end{array}$ & $\begin{array}{l}\text { Shah and } \\
\text { Ward (2003) }\end{array}$ & Unionization, plant age & - & $\begin{array}{l}\text { Development and test of } \\
\text { theory-based contingency } \\
\text { propositions }\end{array}$ & $\begin{array}{l}\text { Inferential } \\
\text { detailed }\end{array}$ & $\mathrm{Y} / \mathrm{Y}$ & S \\
\hline & $\begin{array}{l}\text { Human resource } \\
\text { practices }\end{array}$ & $\begin{array}{l}\text { Ahmad and } \\
\text { Schroeder (2003) }\end{array}$ & Industry & - & $\begin{array}{l}\text { Exploratory analysis of } \\
\text { the effect of context variables } \\
\text { on the degree of use of } \\
\text { practices. No contingency } \\
\text { propositions are developed }\end{array}$ & $\begin{array}{l}\text { Non- } \\
\text { inferential }\end{array}$ & $\mathrm{Y} / \mathrm{Y}$ & S \\
\hline & $\begin{array}{l}\text { Total productive } \\
\text { maintenance }\end{array}$ & $\begin{array}{l}\text { McKone } \\
\text { et al. (1999) }\end{array}$ & $\begin{array}{l}\text { Industry, equipment } \\
\text { age and type, plant } \\
\text { age, unionization }\end{array}$ & - & $\begin{array}{l}\text { Development and test of } \\
\text { hypotheses specifying the } \\
\text { existence of an influence } \\
\text { of context variables on the } \\
\text { degree of use of practices }\end{array}$ & $\begin{array}{l}\text { Inferential } \\
\text { aggregate }\end{array}$ & $\mathrm{Y} / \mathrm{Y}$ & S \\
\hline
\end{tabular}

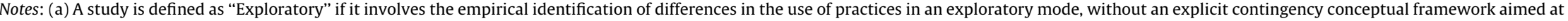

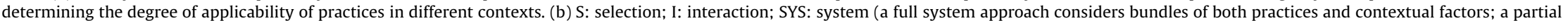
system approach considers bundles of practices or contextual variables, but not both). 
et al., 2001). These approaches have later resulted in what may be called the manufacturing strategy contingency (or fit) paradigm, according to which internal and external consistency between manufacturing strategy choices increases performance (e.g., Hayes and Wheelwright, 1979a,b; Hill, 1985).

We may conclude that from its inception the OM field has been strongly rooted in a contingency paradigm, which has been informed by CT. A possible explanation for this may be CT's economic efficiency and intentional form of rationality and the adoption of a predominantly normative approach (Donaldson, 2001). It has been argued that this stance fits the extant OM paradigms and theories, as well as OM empirical research, which primarily seeks prescriptive insights (Boyer et al., 2005; Ketokivi and Schroeder, 2004b).

Therefore, we take the perspective that CT can be a very useful theoretical lens to view OM issues, in particular in areas where OM theory is less well developed. Consistent with this view, there has been more recent interest in applying CT to OM, primarily in the manufacturing strategy area (Bozarth and McDermott, 1998; Boyer et al., 2000; Ketokivi, 2006).

OM PCR may be seen as the application of the contingency approach to the study of OM best practice. We argue that, similar to the broader OM field, OM PCR shares some of the theoretical assumptions of CT, such as an economic efficiency and normative mindset. However, this occurs only implicitly and this body of research still has limited conceptual foundations and theoretical grounding. We believe that examining OM PCR through the lens of CT - as the major theoretical view on contingencies - can provide important insights and lead to more solid conceptual foundations on which to anchor rigorous research in this area. The organizational level stance of CT fits the expanding scope of the OM field and the cross-functional nature of many of the OM practices. Despite the growing importance of OM PCR, little application of CT has taken place in this area (a notable exception is the work of Ketokivi and Schroeder, 2004b,c). Therefore, we set out to review this body or research against the backdrop of CT. At the end of the article, we discuss some of the limitations of the contingency approach and how other theoretical perspectives may be drawn upon to further enhance our understanding of OM practice contingencies.

\section{Scope of the review of OM PCR}

In the field of $\mathrm{CT}$, contingency studies involve three types of variables. Contextual (or contingency) variables represent situational characteristics usually exogenous to the focal organization or manager. In most instances, the opportunity to control or manipulate these variables is, at best, limited or indirect; even though in some cases the organization or manager is able to change these variables, this is only possible in the long-term and with substantial effort (i.e., they are variables with high inertia). Response variables are the organizational or managerial actions taken in response to current or anticipated contingency factors. Performance variables are the dependent measures and represent specific aspects of effectiveness that are appropriate to evaluate the fit between contextual variables and response variables for the situation under consideration.

Viewed through the lens of CT, OM PCR focuses on the use of OM practices as the organizational response variable. Anchored on the contingency approach, for the purposes of this study we define OM PCR as studies which have as their primary objective the investigation of the effect of high inertia contextual factors on the use and performance outcome of OM practices. We reviewed published studies complying with this definition and have analyzed these on a number of relevant dimensions, which are summarized in Table 1 . We next review the literature across these dimensions grouped along three axes: (i) research variables and measurement; (ii) research design; (iii) employed form of fit. In this process, we identify a number of tasks that future research should undertake in order to move this research area forward.

\section{OM PCR through the lens of CT: researchvariables and measurement}

A fully fledged OM practice contingency model comprises three sets of variables: use of practices, contingency factors and performance. Table 1 shows that, not surprisingly, the most mature sets of practices quality management and lean production, have received the most attention. Best practices in general and these two in particular have been extensively studied in the practiceperformance research stream and have been discussed in the introduction section. In this section, we review OM PCR in terms of: (i) the contingency and performance variables that have been addressed; (ii) measurement issues across the three sets of variables. Examining these two aspects is key for defining OM PCR as a field of study and to foster generalizability and the comparison of results across different studies.

\section{Contingency variables}

The contingency variables examined in the reviewed studies can be grouped into four broad categories: national context and culture, firm size, strategic context, and other organizational context variables. Some contextual variables are specific to OM (e.g., type of production process), while others are borrowed from other fields in which they are typically relevant (e.g., firm size and organizational uncertainty from the CT field). Overall, the scope of organizational context covered in the literature is consistent with Ketokivi and Schroeder's (2004b) classification of contingency factors relevant for OM practices as strategic goals or environmental contingencies.

A first group of studies investigated national context and cultural effects. This was one of the first areas of interest (90s) in OM PCR. This is probably due to the fact that many of the emergent best practices had their origin in one country, Japan. The question then arose of whether these practices could be transplanted to other countries and cultures (e.g., Ebrahimpour and Cullen, 1993; Voss and Blackmon, 1998). More recently, the growth of globalization has 
spurred additional cross-country/cultural research (e.g., Flynn and Saladin, 2006; Sila, 2007). With the exception of Sila (2007), all studies support the existence of contingency effects.

A second group of studies has examined the use of practices across firms of different sizes, in particular, their applicability in smaller firms. Overall, the results vary according to the sets of practices in question. While studies addressing quality management found no evidence of firm size effects (e.g., Ahire and Golhar, 1996), studies addressing lean manufacturing and general manufacturing best practices have found support for such effects (e.g., Cagliano et al., 2001; Shah and Ward, 2003).

A third group of studies examined the use of $\mathrm{OM}$ practices across different strategic contexts, and is generally rooted in the manufacturing strategy contingency paradigm of the OM field. With two exceptions (Hobbs, 1994; Sila, 2007), studies support the existence of strategic context effects. Hence, evidence to date seems to lend support for the manufacturing strategy contingency paradigm.

A final group of studies addresses several loosely related factors associated with the general context of organizations, for example, industry (Ahmad and Schroeder, 2003) and plant age (Shah and Ward, 2003). All of them provide support for contingency effects.

\section{Future research}

We identify a number of issues related to contingency variables that need to be addressed. Apart from national context and firm size, the studies analyzed in Table 1 have employed a wide variety of variables to characterize organizational contexts. Too many contingency variables may limit generalizability and hamper the comparison of results between different studies. Better research could be conducted if it were possible to identify a limited set of contingency variables defined as relevant for the OM discipline and that distinguish between contexts, similar to what has been accomplished in the CT field. The challenge is to identify the contingencies that explain the greatest variance in performance. This identification process might be started with a thorough examination of the literature, drawing both on theoretical grounds (e.g., Sitkin et al., 1994 for strategic context effects) to generate a comprehensive list of factors, and existing empirical results to establish preliminary relevance.

Table 1 also shows that several OM studies employ different contingency variables that could be expected to be highly correlated. For example, Sitkin et al. (1994) and Reed et al. (1996) use as their main contingency variable "organizational uncertainty", while Hendry (1998) addresses the "policy for satisfying customer demand" (make-to-order vs. other policies). From an OM perspective, these two variables might be expected to be highly correlated and might be candidates for collapsing into a more general contingency variable, such as, for instance, "product-process matrix positioning" (e.g., high variety low volume operations might be seen as having high degrees of uncertainty and more frequently employing make-to-order policies, while the reverse would be expected in their low variety - high volume counterparts). Avoiding highly correlated variables provides opportunities to reduce the set of relevant OM contingency variables by consolidating such variables. The development of empirical taxonomies of contextual variables would be a useful avenue to identify a limited set of key variables.

\section{Performance variables}

Organizational performance may be assessed using different types of variables. Therefore, researchers may develop different contingency models directed to achieve different performance objectives (Flynn et al., 1999; Pennings, 1975). For example, the effect of contextual factors on OM practices may be different depending on whether we consider operational or overall business performance.

Table 1 shows that, as in CT, OM PCR studies have employed a variety of types of performance variables, including operational performance, customer satisfaction, human resource results, and market and financial performance. In addition, several have employed different types of variables simultaneously (e.g., Sila, 2007; Koufteros et al., 2005; Das et al., 2000).

\section{Future research}

We recognize the usefulness of examining different contingency models addressing different types of performance variables. However, we propose that, within the realm of OM PCR, special attention should be given to operational performance aspects, although other types of performance might be examined in addition. Implicit in this stance is the assumption that OM contingency theory should aim at producing prescriptive knowledge targeted at increasing an organization's operational performance (which, in turn, may affect other types of performance variables, such as customer satisfaction). Traditional operational variables (also called competitive priorities or operations performance objectives) include cost, quality, delivery and flexibility (e.g., Schmenner and Swink, 1998; Ward et al., 1998). OM PCR research has not addressed operational performance impacts in sufficient depth, and future research could benefit from increasing the examination of contingency models with multiple dimensions of operational performance. Of particular interest would be to examine whether the adequate match between OM practices and context differs according to the operational performance dimension in question (for example, is the set of $\mathrm{OM}$ practices appropriate for a small size operation the same whether we consider cost or flexibility performance?).

\section{Measurement}

The comparability of different contingency studies and their contribution to a cumulative knowledge building process hinge on the existence of established measures (i.e., widely accepted and regularly re-utilized) for the three sets of variables: use of practices, contextual variables and performance. 
Good progress has been made in the OM field in developing measurement instruments for the degree of use of practices (e.g., Ahire et al., 1996; Flynn et al., 1994; Koufteros et al., 1998; Sakakibara et al., 1993). Consistent with this, with the exception of Cagliano et al. (2001), all the studies in Table 1 from the year 2000 onwards employ properly developed scales, often drawing on previously developed instruments (e.g., Sila, 2007; Das et al., 2000; Lai and Cheng, 2003).

However, there is still a paucity of established measures in OM for relevant contextual and organizational performance variables; even contextual variables that are key to OM theory such as volume and variety lack established measures. For example, Roth et al. (2007) in their review of OM metrics have identified 28 developed scales for "plant/process/product type" variables. Many of these studies develop scales for a specific research purpose; as a result, each of these scales typically covers a somewhat specific (and sometimes idiosyncratic) contextual aspect. This limits the broad use of the scales and the potential for their re-utilization. There are many different measures and scales available for measuring the same performance variable. For example White (1996) identified 125 strategy-related measures that have been proposed for measuring manufacturing performance. Roth et al. (2007) lists 12 different scales for measuring a single performance dimension (delivery performance).

This general pattern is reflected in the contingency studies in Table 1. For example, for contextual variables, the studies either developed their own measures for the purpose of their particular objectives (e.g., Voss and Blackmon, 1998; Kathuria and Partovi, 1999), or borrowed established measures from other fields (e.g., Koufteros et al., 2002). This pattern is more apparent in contextual variables more closely related to OM (e.g., strategic context variables, such as type of process) than for those that have been borrowed from other fields (e.g., national context and firm size). Similarly, the studies in Table 1 do not share common performance metrics.

This diversity of measurement affects practice-context-performance relationships and thus may be an explanation for the conflicting findings observed across some of the contingency studies in Table 1. For example, while most studies found an impact of national context and culture on quality management practices, the study by Sila (2007) found none.

\section{Future research}

A consolidation and categorization effort is clearly needed to foster sense making and generalizability. Bringing together extant scales and metrics for general OM research (Roth et al., 2007) is a strong contribution to this. A particular challenge for contingency research is to develop measures that are both valid and comparable across different contexts. Increasing the generalizability of a measure to encompass different contexts may reduce its validity, because better data can be obtained by carefully crafting measures for specific situations (Boyer and Pagell, 2000). Similarly, the use of objective measures is problematic when different contexts are examined, as these measures tend to be context-specific (Ketokivi and Schroeder, 2004a).

We submit two possible ways forward. One is the development of general perceptual measures and scales. This would require research designs which address their limitations, for example by having multiple respondents and adopting appropriate and rigorous examinations of validity (Ketokivi and Schroeder, 2004a). The other is to employ research designs which control for as many relevant factors as possible besides the contextual factors under examination. Such designs increase the likelihood of developing valid measures because such measures are required to span less diverse contexts which only differ in respect to the contextual variables under study. For example, Sousa and Voss's (2001) investigation of strategic context effects was single-industry, which enabled the use of industry-specific measures for relevant research variables, some of them based on objective data. Drawing on the output of the consolidation of contextual variables proposed earlier, OM researchers could also develop measures targeted to a limited set of particularly relevant types of contexts (for example, measures that are valid for a particular product-process matrix positioning that could be used in contingency studies examining contextual factors other than such positioning).

\section{OM PCR through the lens of CT: research design}

In this section we discuss the types of research designs that have been employed, in particular, the associated potential for making valid inferences. We have categorized the research design of the reviewed studies as noninferential, inferential-aggregate and inferential-detailed. Inferential designs are those that allow for the making of rigorous inferences as to the degree of applicability of practices across different contexts. Both conceptual and empirical studies may be considered inferential. A purely conceptual study is considered inferential if precise hypotheses concerning the influence of context on practices are developed. An empirical study is considered inferential if it is backed by an explicit contingency framework and is explicitly designed to test or uncover contingency effects, resulting in the clear identification of the existence or importance of such effects. Within inferential designs, we distinguish between two types of studies: (i) inferential-aggregate: studies which are designed to investigate the existence of differences in the use of practices at an aggregate level (typical format of hypotheses/conclusions: H0: There are differences in the use of a set of practices across different contexts); (ii) inferential-detailed: studies that go beyond the former, and are designed to investigate the existence of differences in the use of practices at a detailed level, specifying the effects of different contexts on individual practices (typical format of hypotheses/conclusions: HO: Practice $\mathrm{X}$ is used to a larger extent in context $\mathrm{Y}$ than in context $\mathrm{Z}$ ).

Of the 35 studies included in Table 1, close to two thirds (24) employ an inferential research design. Of these, 18 studies are classified as inferential-detailed and 6 studies as inferential-aggregate. The rest of the studies (11) remain at the comparison level attempting to uncover differences 
in the use of practices in different contexts, employing an exploratory mode; the contingency stance in these studies is only implicit, in that detected differences may indicate the existence of contingency effects. The large majority of the studies (30) have an empirical component and most of them suggest the existence of relevant contingency effects, which reinforces the importance of conducting contingency research.

\section{Future research}

While existing OM PCR shows a good degree of inferential power, there is room for improvement. An important aspect in designing contingency studies is the choice of the point in time, relative to the initial adoption of a given set of best practices, at which to empirically assess fit. Discussion of this aspect is absent from most of the studies in Table 1. We propose that the assessment of fit in OM PCR should concern the match between context and practices when these have reached a stable level of development. This is for two reasons. The first is related to the need for organizations to resort to experimentation in adopting and selecting practices. In the present business environment of fast diffusion and innovation in managerial concepts, organizations may have no choice but to experiment with many untried innovative practices while searching for a few appropriate ones, because the costs of these experimentations may be much lower than the returns from using the surviving practices (Abrahamson, 1991). The second reason is the generally accepted view that there are time lags between the implementation of practices and their performance effects (e.g., Reed et al., 1996; Hendricks and Singhal, 1997).

This favors the study of mature OM practice settings. Most studies in Table 1 have not controlled for implementation maturity, although their reliance on typically large samples has reduced potentially adverse effects of this lack of control. Ideally, future studies, especially if employing smaller samples, should control for practice maturity. This could be assessed, for example, by estimating the typical length of time for different sets of practices to achieve maturity in an organization or by developing actual measures (or indicators) of maturity. Some research has been conducted in this area for quality management practices (e.g., Ahire, 1996; Dale and Lascelles, 1997), but more research is needed for other OM practices.

\section{OM PCR through the lens of CT: employed form of fit}

In conducting contingency research, different forms of fit can be employed (Doty et al., 1993). Two prominent classifications of forms of fit in CT have been those of Drazin and van de Ven (1985) and Venkatraman (1989). Drazin and van de Ven (1985) consider three distinct forms of fit, based on the configuration of the relationships between contextual, response and performance variables that are examined (selection, interaction and system approach). Venkatraman (1989) puts forward six different forms of fit based on the degree of precision of the functional form of fit and the number of variables

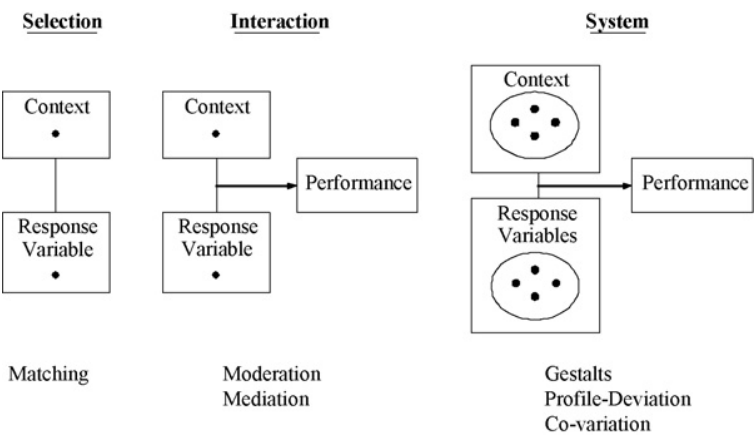

Fig. 1. The selection, interaction and system forms of fit (Drazin and van de Ven, 1985) and correspondence with Venkatraman's (1989) six forms of fit.

considered in the fit equation (moderation, mediation, matching, gestalts, profile-deviation and co-variation).

In this section, we examine OM PCR studies according to the form of fit that they employ and discuss their different roles in generating contingency knowledge. Due to its parsimony, we employ Drazin and van de Ven's (1985) classification. Fig. 1 summarizes this classification and its correspondence with Venkatraman's (1989) categories.

In the selection approach, fit is seen as a basic assumption underlying congruence propositions between the organizational context and response variables. This approach does not examine whether the proposed context-response relationships affect performance. Table 1 shows that there has been substantial use of the selection approach (24 studies), fairly well spread out across the four groups of contextual variables. The interaction approach sees fit as the interaction of pairs of organizational contextresponse variables which affects performance. Table 1 shows that the use of the interaction approach has been lower (7 studies).

The selection and interaction approaches tend to focus on how single contextual factors affect single response variables. Advocates of the system approach argue that the understanding of context-response relationships must address simultaneously the many contingencies, response alternatives and performance criteria that must be considered holistically to understand organizational design. Fit is seen as the internal consistency of multiple contingencies and multiple response variables which affects performance characteristics. The system approach has recently incorporated the concept of equifinality by interpreting fit as feasible sets of equally effective alternative designs, with each design internally consistent in its structural pattern and with each set matched to a configuration of contingencies facing the organization (e.g., Doty et al., 1993; van de Ven and Drazin, 1985). In simple terms, the equifinality argument states that there are multiple, equally effective ways in which an organization can achieve fit.

In OM, a system view of practices has been adopted by a number of authors. In the practice-performance stream a number of studies have found evidence of strong interactions between several OM practices (e.g., Cua et al., 2001; Flynn et al., 1999; Kaynak, 2003; Shah and Ward, 2003. 
2007), suggesting that besides their individual effects, their mutual interactions significantly affect performance. However, the use of the system approach in OM PCR has been limited. Table 1 shows that only four studies employed this approach. Of these, two have adopted a full system approach, considering bundles of practices and contextual variables (Sousa, 2003; Sousa and Voss, 2001), and two other have adopted only a partial system approach, considering bundles of practices, but examining contextual variables individually (Koufteros et al., 2002, 2005). Within the system approach, we found the equifinality argument to be absent from the OM PCR studies in Table 1.

We observed that OM PCR studies have not explicitly considered the existence of distinct forms of fit. This is consistent with the fact that many of these studies did not position themselves as contingency studies. In addition, the literature review seems to show a natural progression of knowledge-building along time. Studies employing the selection approach have been the earliest to appear, and many have employed non-inferential designs. In contrast, all empirical studies employing the interaction and system approaches have been published after 2000 and all employ inferential designs. Finally, we did not find any OM PCR studies which performed triangulation between the three approaches to fit.

\section{Future research}

We identify two main research needs. The first is to increase the use of the system view in OM PCR. Two possible reasons may explain the sparse use of the system approach. One may be the reductionistic approach that is dominant in OM empirical research, whereby organizations such as manufacturing plants are studied by breaking them into their constituent parts (Ketokivi and Schroeder, 2004 b, p. 64). Another reason may be the difficulties that are involved in addressing complex forms of interactions among variables. We put forward several suggestions to increase the use of the system view in OM PCR. First, OM PCR scholars should consider the application of configurational research methods (Meyer et al., 1993), an endeavor that has already been embraced by research in operations strategy (Bozarth and McDermott, 1998; Boyer et al., 2000). Second, OM PCR scholars may readily draw on work such as Venkatraman's (1989), which provides an overview of analytical methods that can be used to test system forms of fit, including profile deviation approaches (Venkatraman and Prescott, 1990), which have been employed in other areas of OM (e.g., Ahmad and Schroeder, 2003; Das et al., 2006; da Silveira, 2005). These analytical methods, based on several statistical techniques, are ideally suited to the survey methodology, which has been the most frequently used method in OM PCR. Third, OM scholars may wish to increase the use of methodologies oriented towards theory building, such as case research. Whilst survey research is excellent for identifying contingency effects, case research can be a better method for building explanations for the observed effects, an important requirement for system approaches. Associated data analysis methods such as "causal networks" (Miles and
Huberman, 1994) can be especially useful to analyze networks of causal relationships between the research variables (the system studies by Sousa (2003) and Sousa and Voss (2001) in Table 1 are examples of the application of this method in OM). Finally, the previously mentioned need for the development of taxonomies of contextual variables would also facilitate the use of system fit approaches.

The second main research need is to recognize and combine different approaches to fit, on a journey of cumulative theory building. Different forms of fit are not mutually exclusive and can provide unique and complementary information (Drazin and van de Ven, 1985; Venkatraman, 1989). We next discuss the insights that the use of each of the three main forms of fit singly and in combination can provide, and give examples of how they have been and/or could be applied in OM PCR.

The selection approach can be useful for exploring important relationships between context and OM practices. This information can then be used for the generation of contingency propositions for future tests incorporating the performance dimension (Drazin and van de Ven, 1985). For example, Rungtusanatham et al.'s (1998) empirical results using a selection approach raised the possibility of national culture affecting workforce management practices. These findings could be used to generate appropriate contingency propositions for future tests incorporating performance.

The interaction approach can be used to identify the most critical context-practice relationships. If the use of such approach detects fit, but only among certain pairs of context-practice relationships, such findings would indicate that those context-practice matches are more relevant predictors of performance than others (Drazin and van de Ven, 1985). Such findings would be of great practical utility, implying that limited resources should be allocated to the most critical context-practice relationships. For example, Kathuria and Partovi (1999) found that the degree of fit between the context variable emphasis on manufacturing flexibility and two types of HRM practices (relationship-oriented practices and participative leadership and delegation practices), but not a third type of HRM practice (work-oriented practices), had a significant effect on managerial performance. Hence, managers aiming at achieving contextual fit of HRM practices should focus their efforts on the first two practices and might ignore the third.

Whenever the contingency theory in question is based on configurations of variables, it is recommended that interaction results be compared with system results (Drazin and van de Ven, 1985). If the interaction results are not significant, but the system results are, then it can be reasonably concluded that fit does not occur at the level of any individual variable alone but rather at the level of deviation from an overall pattern of variables (i.e., the effects of fit are present at a holistic level). The system approach can also be useful when it is possible that conflicting contingencies are present (e.g., one contextual factor specifies a high use of a practice as the fit and a second contextual factor specifies a low use of the same practice as the fit). Finally, the system approach could be 


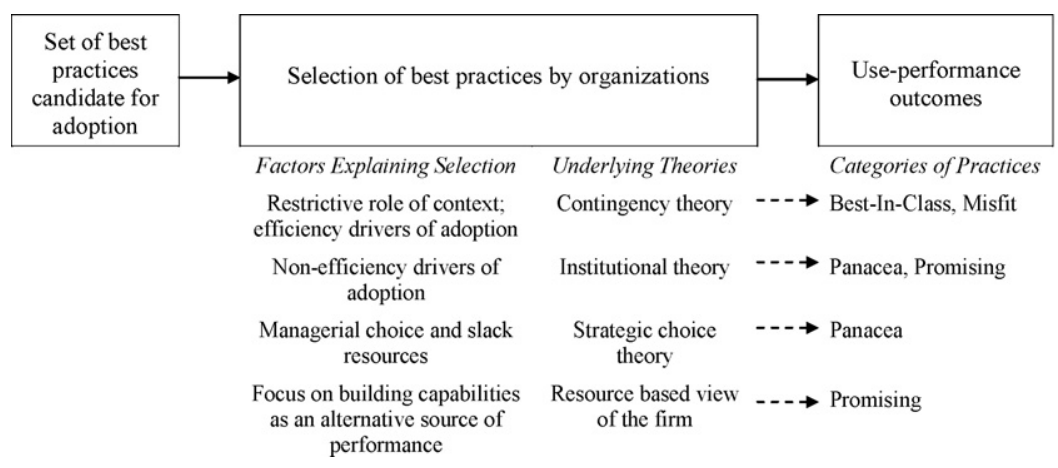

Fig. 2. A framework for understanding the process of selection of OM practices leading to observed patterns of use of practices and associated performance outcomes.

used to address equifinality in OM PCR. Of particular interest would be for future research to ascertain whether there are multiple, equally effective ways of achieving fit between the set of OM practices to adopt and an organization's context.

\section{Further research incorporating additional theoretical perspectives}

Underlying OM PCR is a notion of fit that is rooted on CT, based on an economic rationality and a design-oriented mindset (i.e., the prescription of organizational responses/ designs to contingencies) (Ketokivi and Schroeder, 2004b). Although OM PCR may produce advice on which practices an organization should adopt to achieve fit, on its own it does not seem to fully explain the actual observed patterns of use of practices and associated performance outcomes in the present business environment. Recent research has provided evidence that we may find organizations with mature OM practice programs with long-term deviations from fit (Ketokivi and Schroeder, 2004b; Sila, 2007). Therefore, a more complete understanding of OM practice contingencies, and in particular, producing advice on steering organizations into fit, requires the understanding of deviations from contingency-determined patterns, a theme which has been largely overlooked in current OM PCR.

In order to accomplish this, we need to achieve a deeper understanding of the process of selection of practices by organizations (decisions to adopt, maintain or discontinue the use of practices) leading to the currently observed patterns of use of practices and associated performance outcomes. We propose a framework to underpin such research (Fig. 2) and suggest two main avenues for future work, overcoming the limitations of the contingency approach: (i) understanding the causes of deviations from contingency-determined patterns; (ii) empirically characterizing the current status of these deviations. These are discussed next.

\section{Understanding the causes of deviations from contingency-determinedpatterns}

In a mature practice implementation program in an organization, we may find four possible situations for practices according to their patterns of use and performance outcomes in that organization's context: Best-InClass (high use, high fit - high performance), Misfit (low use, low fit - low performance), Panacea (high use, low fit low performance), and Promising (low use, high fit - high performance). Table 2 summarizes the four categories of practices and provides possible examples from OM according to current contingency knowledge.

According to contingency arguments, organizations should use practices which are effective in their context (i.e., with adequate fit) to a high degree and use ineffective practices to a low degree. Therefore, while these arguments can explain the existence of Misfit and Best-In-Class practices in organizations, they cannot explain the observation of Panacea and Promising practices in mature practice programs. Hence, we submit as a fruitful way forward to draw on other theoretical perspectives to seek explanations for how selection may result in deviations from the patterns predicted by $\mathrm{CT}$. We identify three promising theories that address some of the limitations of CT: institutional theory (DiMaggio and Powell, 1983), strategic choice theory (Child, 1972) and the resourcebased view of the firm (Barney, 1991). These are discussed next.

The contingency perspective assumes that practices are adopted due to efficiency factors, i.e., with the direct objective of improving technical performance. The institutional perspective argues that practices can also be adopted due to non-efficiency (institutional) factors, so as to gain legitimacy whether or not the practices may lead to an increase in technical performance. These factors are usually classified into coercive, mimetic and normative pressures (DiMaggio and Powell, 1991). These pressures may break the context (or efficiency) barrier leading organizations to take a conscious decision to use a practice long-term which is perceived as non-effective in their context (Barreto and Baden-Fuller, 2006). These may explain Panacea practices. Non-efficiency pressures could also lead to the low use of efficient practices. For example, powerful outside organizations with vested interests (e.g., governmental regulators or labor unions) may exert political pressures discouraging (or at least, not encouraging) the use of particular practices (Abrahamson, 1991). In addition, there may be newer practices which may be less well known and their fit and effectiveness uncertain. These 


\section{Degree of use}

\begin{tabular}{|c|c|c|}
\hline & Low & High \\
\hline & Misfit & Panacea \\
\hline 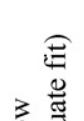 & $\begin{array}{l}\text { Example: Kanban coordination in manufacturing } \\
\text { processes with high product variety and complex } \\
\text { routings. }\end{array}$ & $\begin{array}{l}\text { Example: Heavily bureaucratic ISO9001 certified } \\
\text { quality management systems in small organizations. }\end{array}$ \\
\hline 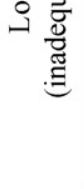 & $\begin{array}{l}\text { Suggested action: Practice should be discarded from } \\
\text { the set of alternatives for the organization's context. }\end{array}$ & $\begin{array}{l}\text { Suggested action: Practice is used for reasons other } \\
\text { than its effectiveness (institutional pressures, } \\
\text { managerial choice/slack resources). The organization } \\
\text { should attempt to remove pressures for use, and then } \\
\text { discard it. }\end{array}$ \\
\hline & Promising & Best-In-Class \\
\hline & $\begin{array}{l}\text { Example: Total Productive Maintenance in machine } \\
\text { intensive environments. }\end{array}$ & $\begin{array}{l}\text { Example: JT manufacturing practices in high-volume, } \\
\text { repetitive production. }\end{array}$ \\
\hline 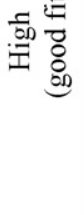 & $\begin{array}{l}\text { Suggested action: Practice is less used due to lack of } \\
\text { knowledge or reasons other than its effectiveness } \\
\text { (institutional pressures, focus on sources of } \\
\text { performance other than best practices). The } \\
\text { organization should evaluate its use and/or remove the } \\
\text { pressures against its use. }\end{array}$ & $\begin{array}{c}\text { Suggested action: Practice is part of the basic set of } \\
\text { practices for the organization to implement in its } \\
\text { context. }\end{array}$ \\
\hline
\end{tabular}

Notes: (a) The degree of use and performance refer to stable patterns in the context of a mature practice implementation. Degree of use refers to the intensity (depth and breadth) of the implementation of a practice. (b) The patterns of use associated with Panacea and Promising practices cannot be explained by contingency arguments.

two effects may result in these practices having reduced visibility in the radar of managers who are looking for the adoption of best practices. These factors may explain the existence of Promising practices (practices have unfulfilled promise).

Both efficiency and non-efficiency factors have been empirically identified as drivers of adoption of $\mathrm{OM}$ practices in manufacturing operations. Table 3 provides detailed examples of these drivers. Recent studies have combined rational explanations with institutional arguments to explain the use of OM practices and have concluded that institutional arguments have strong explanatory power. Examined practices have included innovative manufacturing practices (Ketokivi and Schroeder, 2004b), quality management (Sila, 2007) and supplier development practices (Rogers et al., 2007). Hence, institutional theory emerges as a promising theoretical perspective to explain deviations from contingencydetermined patterns.

The contingency approach assumes that it is the contingencies that, in the long run, determine organizational responses (there may be temporary deviations from fit, but the corresponding detrimental effect on performance will, in the long run, force organizations back into fit) (Donaldson, 2001). This stance has been criticized for leaving little scope for free managerial choice. As a result, Child (1972) has proposed strategic choice theory which takes the contingency theory of organizations, but allows for some degree of choice. The rationale for this theory is that organizations may have slack resources, therefore avoiding the need to be in full fit. In this way, organiza- tional responses are not completely determined by contingencies and instead managers have some degree of choice. This is consistent with the notion of quasi-fit recently introduced by proponents of CT (Donaldson, 2001, p. 257). In OM, it is a well-accepted notion that the Operations function and Operations managers have some degree of choice in the composition of best practice programs (e.g., Chase et al., 2006; Hayes and Pisano, 1994; Hill, 1985). Therefore, strategic choice theory could be an additional explanation for the use of ineffective practices (Panaceas), as long as the use of most practices in the overall OM practice program is determined by contingencies (i.e., it might explain why an organization may survive with a high use of a few ineffective practices, as long as a good part of its practice program displays overall low use of ineffective practices and high use of effective practices).

CT also assumes that performance is mainly determined by the level of fit. In OM, it has been proposed that there are three main sources of performance, in what have become known as the three paradigms of manufacturing strategy: best practices, fit and the development of capabilities (Voss, 1995). Consistent with CT, in OM PCR performance is seen as being mainly determined by the level of fit of practices with the organizational context. Therefore, the development of capabilities emerges as an important source of performance not contemplated by the contingency approach underlying OM PCR (Schroeder et al., 2002). The capabilities paradigm is rooted in the resourcebased view of the firm (Barney, 1991), according to which performance results from resources which are valuable, difficult to obtain and hard to imitate or trade. This theory 
Table 3

Examples of different types of drivers of adoption and use of OM practices in manufacturing operations

\begin{tabular}{ll}
\hline Type of driver & Examples substantiated with empirical evidence \\
\hline Efficiency & Profits squeezed under competitive pressure, lost \\
market share due to entry by foreign companies, \\
changes in market structure, rationalization following \\
market contraction (e.g., Lascelles and Dale (1986) for \\
quality management; Billesbach (1991), Chen (1991) for JIT). \\
Degree of international competition (e.g., Das et al. & (2000) for quality management).
\end{tabular}

\author{
Non-efficiency (Institutional) (a) \\ Coercive pressures: Organizations adopt certain practices \\ because of pressure from the state, other \\ organizations or the wider society
}

Normative pressures: In certain sectors with professionalized personnel status competition playing to professional criteria can significantly influence the form of the adopted organizational structure

\author{
Customer pressure (e.g., Billesbach (1991) for JIT; \\ Anderson et al. (1999) for ISO9000 certification; \\ Juran (1993) for quality management; numerous \\ reported cases for statistical process control, \\ e.g., Schneider et al. (1995)) \\ Legitimization pressures (numerous publicized \\ cases, e.g., image building and gaining credibility \\ with potential customers by achieving ISO9000 \\ certification, Anderson et al. (1999)) \\ Pressures from the parent company already \\ using the practices (numerous reported \\ cases, e.g., Billesbach (1991) for JIT). \\ Legal requirements (e.g., regulatory pressure \\ for ISO9000 certification, Anderson et al. (1999), Guler et al. (2002)). \\ Fad/fashion effects (numerous reported \\ cases, e.g., Dale et al., 2001) \\ Imitation of Japanese manufacturing practices \\ (e.g., Ebrahimpour and Cullen (1993)). \\ Benchmarking exercises (numerous reported \\ cases, e.g., Myers and Heller (1995), Voss et al. (1997)). \\ Global network effects (e.g., the international \\ spread of ISO9000 practices through business ties, \\ Anderson et al. (1999), Guler et al. (2002)).
}

Mimetic pressures: As a result of bounded rationality and limits on time, energy, as well as substantial uncertainty regarding the efficiency of perceived to be legitimate practices

(a) Most institutional studies concentrate on mimetic and coercive pressures. Normative pressures are only prevalent in specific contexts, and are likely to be less relevant in manufacturing contexts, the focus of this article. Therefore, the examples in the table follow the stance adopted by Ketokivi and Schroeder (2004b) of not clearly differentiating normative from coercive pressures.

may be a particularly relevant explanation for why some firms may deliberately choose not to adopt efficient practices and rather opt to invest their effort in other sources of performance advantage, thus justifying the existence of Promising practices. These other sources of performance could also result in the generation of slack resources allowing for less than ideal situations of fit in best practice programs.

In summary, in the perspective of our framework (Fig. 2), OM PCR is important in generating prescriptive knowledge about the technical fit of OM practices to different contexts. Context is expected to play an important role by restricting managerial choice (Ketokivi, 2006) and working as an efficiency filter shaping the set of practices used by an organization. However, we have proposed that the extent to which context determines the use of practices may depend on other factors such as the level of institutional pressures for adoption and use of practices, managerial choice/existence of slack resources and the focus on alternative sources of performance such as capabilities. Future research should examine the relative explanatory power and interplay of contingency, institutional, managerial choice, resource-based or other theoretical arguments in best practice adoption and use. Of particular interest would be to perform detailed case studies of "out-of-fit" organizations. An excellent example of research in this area is the work of Rogers et al. (2007) who studied how operations managers reconcile institutional pressures with the pressures to operate efficiently.

\section{Characterizing the current status of deviations from contingency-determined patterns}

From a practical perspective it would be important to study deviations from contingency-determined patterns in order to ascertain whether there are cross-organizational forces shaping these patterns. This could be done by studying mature $\mathrm{OM}$ practice implementations across different types of contexts (e.g., high vs. low volume production) and observing the associated patterns of use of practices and respective performance outcomes (thus employing an interaction or system form of fit). If a given practice is found to fall under the same category (Misfit, Panacea, Promising, Best-In-Class) across many organizations representing a given context type, this may mean that there are cross organizational forces causing these patterns (including deviations from contingency-determined patterns) and that we may be able to arrive at a classification of practices which may be valid and generalizable for that context type.

These results would open the way for interventions at the level of the practitioner community as a whole. They 
could be used by OM scholars in diffusing knowledge and interacting with the business community, discouraging the adoption of Panacea and Misfit practices, encouraging the use of Best-In-Class practices, and promoting Promising practices to Best-In-Class status when appropriate. Given the timescale to produce this knowledge, it would benefit the late adopters, reducing the likelihood of inadequate decisions in best practice adoption and use. However, early adopters might also benefit in the sense that this knowledge may help scholars and firms to predict fit and misfit issues in emerging practices (e.g., enabling the identification early on in the adoption cycle of the potential misfit situations of emerging practices; for example, the contingency knowledge that we have learned for Quality Management practices may help understand contingencies associated with Six Sigma practices). In addition, individual organizations could use such knowledge to evaluate fit by comparing their current OM practice adoption state with the prescribed state for their context type. Based on our proposed framework, Table 2 suggests an action roadmap for businesses to achieve contextual fit and highlights the fact that different categories of practices elicit different courses of action in the journey to fit.

\section{Conclusions}

We set out to review OM PCR through the lens of the contingency approach. This review revealed the lack of a unifying research framework and common terminology. Accordingly, we identified a number of areas that OM researchers need to address in moving OM PCR forward: to identify and consolidate relevant contingency variables by developing parsimonious context classifications; to address operational performance impacts in greater depth; to develop established measures of contextual and performance variables; to employ research designs which control for implementation effects; and to recognize and combine the selection, interaction and system approaches to fit. We are confident that addressing these areas will result in the building of more solid conceptual foundations for OM PCR and in a better definition of this body of research as an area of study in OM.

OM PCR is important for generating prescriptive knowledge about the technical fit of OM practices to different contexts. However, we concluded that in order to understand deviations from fit and possibly develop courses of action in the business community to encourage fit, OM scholars need to study in more depth the process of selection of best practices. We put forward a framework describing this process with the objective of underpinning such research. We concluded that an adequate understanding of the practice selection process would benefit from incorporating other theories, specifically, institutional theory, strategic choice theory and the resourcebased view of the firm.

Our review indicated that contextual factors significantly influence the use and performance outcome of OM practices, reinforcing the need to have a more sophisticated contingency theory. Contingency research is impor- tant both for the development of the OM field and for practitioners. From a scientific perspective, OM should provide theories that are useful across a spectrum of contexts. This more complete theory would not only stipulate relationships between adoption of best practice and performance, but would also closely specify the contexts in which they are expected to occur. This in turn would have several benefits. First, it would facilitate theory-testing procedures by directing efforts to disproving theories in the known situations in which they should apply. Second, identifying relevant contextual factors would contribute to increasing the confidence in the results of empirical research. Even if these contextual variables are not the main purpose of the studies, controlling for as many relevant factors as possible increases the likelihood that findings will not be affected by factors other than those specifically under consideration. Finally, increasing our knowledge about the influence of context would guide the selection of the unit of analysis for research. For example, if plant level characteristics are relevant for a particular line of inquiry, then the study should be conducted at plant level, rather than at corporate level.

Contingency knowledge is also important for practitioners, because the failure to acknowledge the limits of applicability of OM practices may lead to their application in contexts to which they are not suitable. This reduces the chances of success, with the risk of discrediting practices whose validity, although not universal, might certainly hold in appropriate contexts. Contingency research can provide guidelines for the selection of the set of $\mathrm{OM}$ practices that is most appropriate for a given organizational context. These guidelines can inform the implementation of improvement programs based on the adoption of OM best practice.

Overall, it is hoped that these reflections will contribute to facilitating the building of formalized and sophisticated forms of contingency knowledge in OM practice, as sets of $\mathrm{OM}$ best practices mature and become increasingly ingrained in business settings.

\section{Acknowledgments}

This research has been funded by the ESRC, grant RES331-25-0027, through the Advanced Institute of Management Research, and by the British Council and the Council of Rectors of Portuguese Universities (CRUP) under the Treaty of Windsor Joint Research Program (grant B-53/07). We also thank four anonymous reviewers, the Editor and Associate Editor for their constructive and helpful comments.

\section{References}

Abrahamson, E., 1991. Managerial fads and fashions: the diffusion and rejection of innovations. Academy of Management Review 16 (3), 586-612.

Ahire, S., 1996. TQM age versus quality: an empirical investigation. Production and Inventory Management Journal First Quarter, 18-23.

Ahire, S., Golhar, D., 1996. Quality management in large vs. small firms. Journal of Small Business Management 34 (2), 1-13. 
Ahire, S., Golhar, D., Waller, M., 1996. Development and validation of TQM implementation constructs. Decision Sciences 27 (1), 23-56.

Ahmad, S., Schroeder, R., 2003. The impact of human resource management practices on operational performance: recognizing country and industry differences. Journal of Operations Management 21 (1), 19-43.

Amundson, S., 1998. Relationships between theory-driven empirical research in operations management and other disciplines. Journal of Operations Management 16 (4), 341-359.

Anderson, S., Daly, J., Johnson, M., 1999. Why firms seek ISO9000 certification: regulatory compliance or competitive advantage? Production and Operations Management 8 (1), 28-43.

Barney, J., 1991. Firm resources and sustained competitive advantage. Journal of Management 17 (1), 99-120.

Barreto, I., Baden-Fuller, C., 2006. To conform or to perform? Mimetic behaviour, legitimacy-based groups and performance consequences. Journal of Management Studies 43 (7), 1559-1581.

Benson, G., Saraph, J., Schroeder, R., 1991. The effects of organizational context on quality management: an empirical investigation. Management Science 37 (9), 1107-1124.

Billesbach, T., 1991. A study of the implementation of just-in-time in the United States. Production and Inventory Management Journal 32 (3) $1-4$.

Bowman, R., 1996. Has JIT flopped? Distribution 95 (7), 2-31.

Boyer, K., Pagell, M., 2000. Measurement issues in empirical research: improving measures of operations strategy and advanced manufacturing technology. Journal of Operations Management 18 (3) $361-374$

Boyer, K., Bozarth, C., McDermott, C., 2000. Configurations in operations: an emerging area of study. Journal of Operations Management 18 (6), 601-604.

Boyer, K., Swink, M., Rosenzweig, E., 2005. Operations strategy research in the POMS journal. Production and Operations Management 14 (4), 442-449.

Bozarth, C., McDermott, C., 1998. Configurations in manufacturing strategy: a review and directions for future research. Journal of Operations Management 16 (4), 427-439.

Buhman, C., Kekre, S., Singhal, J., 2005. Interdisciplinary and interorganizational research: establishing the science of enterprise networks. Production and Operations Management 14 (4), 493 513.

Cagliano, R., Blackmon, K., Voss, C., 2001. Small firms under MICROSCOPE: international differences in production/operations management practices and performance. Integrated Manufacturing Systems 12 (6/7), 469-482.

Chase, R., Jacobs, F., Aquilano, N., 2006. Operations Management for Competitive Advantage. McGraw-Hill, New York.

Chen, F., 1991. Issues in just-in-time implementation: a survey of Western Michigan firms. In: Satir, A. (Ed.), Just-in-Time Manufacturing Systems: Operating Planning and Control Issues. Elsevier, New York, pp. 361-369.

Child, J., 1972. Organizational structure, environment, and performance: the role of strategic choice. Sociology 6, 1-22.

Cua, K., McKone, K., Schroeder, R., 2001. Relationships between implementation of TQM, JIT, and TPM and manufacturing performance. Journal of Operations Management 19 (6), 675-694

da Silveira, G., 2005. Market priorities, manufacturing configuration, and business performance: an empirical analysis of the orderwinners framework. Journal of Operations Management 23 (2) 662-675.

Dale, B., Lascelles, D., 1997. Total quality management adoption: revisiting the levels. The TQM Magazine 9 (6), 418-428.

Dale, B., Elkjaer, M., van der Wiele, A., Williams, A., 2001. Fad, fashion and fit: an examination of quality circles, business process re-engineering and statistical process control. International Journal of Production Economics 73 (2), 137-152.

Das, A., Handfield, R., Calantone, R., Ghosh, S., 2000. A contingent view of quality management-the impact of international competition on quality. Decision Sciences 31 (3), 649-690.

Das, A., Narasimhan, R., Talluri, S., 2006. Supplier integration-finding an optimal configuration. Journal of Operations Management 24 (5), 563-582.

DiMaggio, P., Powell, W., 1983. The iron cage revisited: institutionalized isomorphism and collective rationality in organizational fields. American Sociological Review 48 (2), 147-160.

DiMaggio, P., Powell, W., 1991. Introduction. In: Powell, W., DiMaggio, P. (Eds.), The New Institutionalism in Organizational Analysis. University of Chicago Press, Chicago.

Donaldson, L., 2001. The Contingency Theory of Organizations. Sage Publications.
Dooyoung, S., Kalinowski, J., El-Enein, G., 1998. Critical implementation issues in total quality management. SAM Advanced Management Journal 63 (1), 10-14.

Doty, D., Glick, W., Huber, G., 1993. Fit, equifinality, and organizational effectiveness: a test of two configurational theories. Academy of Management Journal 36 (6), 1196-1250.

Dow, D., Samson, D., Ford, S., 1999. Exploding the myth: do all quality management practices contribute to superior quality performance? Production and Operations Management 8 (1), 1-27.

Drazin, R., van de Ven, A., 1985. Alternative forms of fit in contingency theory. Administrative Science Quarterly 30 (4), 514-539.

Ebrahimpour, M., Cullen, J., 1993. Quality management in Japanese and American firms operating in the US: a comparative study of styles and motivational beliefs. Management International Review 33 (1) $23-38$

Flynn, B., Saladin, B., 2006. Relevance of Baldrige constructs in an international context: a study of national culture. Journal of Operations Management 24 (5), 583-603.

Flynn, B., Schroeder, R., Sakakibara, S., 1994. A framework for quality management research and an associated measurement instrument. Journal of Operations Management 11 (4), 339-367.

Flynn, B., Schroeder, R., Sakakibara, S., 1995. The impact of quality management practices on performance and competitive advantage. Decision Sciences 26 (5), 659-692.

Flynn, B., Schroeder, R., Flynn, E., 1999. World class manufacturing: an investigation of Hayes and Wheelwright's foundation. Journal of Operations Management 17 (3), 249-269.

Fullerton, R., McWatters, C., Fawson, C., 2003. An examination of the relationships between JIT and financial performance. Journal of Operations Management 21 (4), 383-404.

Funk, J., 1995. Just-in-time manufacturing and logistical complexity: a contingency model. International Journal of Operations \& Production Management 15 (5), 60-71.

Ghobadian, A., Gallear, D., 1996. Total quality management in SMEs. Omega 24 (1), 83-106.

Ghobadian, A., Gallear, D., 1997. TQM and organization size. International Journal of Operations \& Production Management 17 (2) 121-163.

Gonzalez-Benito, J., 2002. Effect of the characteristics of the purchased products in JIT purchasing implementation. International Journal of Operations \& Production Management 22 (7/8), 868-886.

Guler, I., Guillén, M., Macpherson, J., 2002. Global competition, institutions, and the diffusion of organizational practices: the international spread of ISO9000 quality certificates. Administrative Science Quarterly 47 (2), 207-232.

Handfield, R., 2006. The state of JOM: an outgoing editor's retro(spective). Journal of Operations Management 24 (5), 417-420.

Hayes, R., Pisano, G., 1994. Beyond world-class: the new manufacturing strategy. Harvard Business Review 72 (1), 77-86.

Hayes, R., Wheelwright, S., 1979a. Link manufacturing process and product life cycles. Harvard Business Review January/February, $133-140$

Hayes, R., Wheelwright, S., 1979b. The dynamics of process-product life cycles. Harvard Business Review March/April, 127-136.

Hayes, R., Wheelwright, S., 1984. Restoring Our Competitive Edge: Competing Through Manufacturing. Wiley, New York.

Hendricks, K., Singhal, V., 1997. Does implementing an effective TQM program actually improve operating performance? Empirical evidence from firms that have won quality awards. Management Science 43 (9), 1258-1274.

Hendry, L., 1998. Applying world class manufacturing to make-to-order companies: problems and solutions. International Journal of Operations \& Production Management 18 (11), 1086-1100.

Hill, T., 1985. Manufacturing Strategy: The Strategic Management of the Manufacturing Function. MacMillan, London.

Hobbs, O., 1994. Application of JIT techniques in a discrete batch job shop. Production and Inventory Management Journal First Quarter, 43-47.

James-Moore, S., Gibbons, A., 1997. Is lean manufacture universally relevant? An investigative methodology. International Journal of Operations \& Production Management 17 (9), 899-911.

Jayaram, J., Droge, C., 1999. The impact of human resource management practices on manufacturing performance. Journal of Operations Management 18 (1), 1-20.

Juran, J., 1993. Assessing quality growth in the US. Quality 32 (10), 48.

Kathuria, R., Partovi, F., 1999. Work force management practices for manufacturing flexibility. Journal of Operations Management 18 (1), 21-39.

Kaynak, H., 2003. The relationship between total quality management practices and their effects on firm performance. Journal of Operations Management 21 (4), 405-435. 
Ketokivi, M., 2006. Elaborating the contingency theory of organizations: the case of manufacturing flexibility strategies. Production and Operations Management 15 (2), 215-228.

Ketokivi, M., Schroeder, R., 2004a. Perceptual measures of performance: fact or fiction? Journal of Operations Management 22 (3), $247-$ 264.

Ketokivi, M., Schroeder, R., 2004b. Strategic, structural contingency and institutional explanations in the adoption of innovative manufacturing practices. Journal of Operations Management 22 (1), 63-89.

Ketokivi, M., Schroeder, R., 2004c. Manufacturing practices, strategic fit and performance: a routine-based view. International Journal of Operations \& Production Management 24 (2), 171-191.

Koufteros, X., Vonderembse, M., Doll, W., 1998. Developing measures of time-based manufacturing. Journal of Operations Management 16 (1), 21-41.

Koufteros, X., Vonderembse, M., Doll, W., 2002. Integrated product development practices and competitive capabilities: the effects of uncertainty, equivocality and platform strategy. Journal of Operations Management 20 (4), 331-355.

Koufteros, X., Vonderembse, M., Jayaram, J., 2005. Internal and external integration for product development: the contingency effects of uncertainty, equivocality, and platform strategy. Decision Sciences 36 (1), 97-133.

Lai, K., Cheng, E., 2003. Initiatives and outcomes of quality management implementation across industries. Omega 31 (2), 141-154.

Lascelles, D., Dale, B., 1986. How change agents can effect quality improvement. In: Proceedings of the Second National Conference on Production Research, UK, pp. 132-145.

Lawler, E., 1988. Choosing an involvement strategy. Academy of Management Executive 11 (3), 205-212.

Lawrence, P., Lorsch, J., 1967. Organization and Environment: Managing Differentiation and Integration. Division of Research, Graduate School of Business Administration, Harvard University, Boston.

Maddow, J., 1995. Time to demystify JIT. Transportation \& Distribution 36 (10), 76.

McKone, K., Schroeder, R., 2001. The impact of total productive maintenance practices on manufacturing performance. Journal of Operations Management 19 (1), 39-57.

McKone, K., Schroeder, R., Cua, K., 1999. Total productive maintenance: a contextual view. Journal of Operations Management 17 (2), 123-144.

Mersha, T., 1997. TQM implementation in LDCs: driving and restraining forces. International Journal of Operations \& Production Management 17 (2), 164-183.

Meyer, A., Tsui, A., Hinings, C., 1993. Configurational approaches to organizational analysis. Academy of Management Journal 36 (6), 1175-1195.

Miles, M., Huberman, A., 1994. Qualitative Data Analysis: An Expanded Sourcebook, 2nd ed. SAGE Publications, Beverly Hills, CA.

Myers, D., Heller, J., 1995. The dual role of AT\&T's self-assessment process. Quality Progress 28 (1), 79-83.

Oliver, N., Delbridge, R., Lowe, J., 1996. The European auto components industry: manufacturing performance and practice. International Journal of Operations \& Production Management 16 (11), 85-97.

Pennings, J., 1975. The relevance of the structural-contingency model for organisational effectiveness. Administrative Science Quarterly 20 (3), 393-410.

Powell, T., 1995. TQM as competitive advantage: a review and empirical study. Strategic Management Journal 16 (1), 15-37.

Reed, R., Lemak, D., Montgomery, J., 1996. Beyond process: TQM content and firm performance. Academy of Management Review 21 (1), 173-202.

Rogers, K., Purdy, L., Safayeni, F., Duimering, P., 2007. A supplier development program: rational process or institutional image construction? Journal of Operations Management 25 (2), 556-572.

Roth, A., Schroeder, R., Huang, X., Kristal, M., 2007. Handbook of Metrics for Research in Operations Management. Sage Publications.

Rungtusanatham, M., Forza, C., Filippini, R., Anderson, J., 1998. A replication study of a theory of quality management underlying the Deming management method: insights from an Italian context. Journal of Operations Management 17 (1), 77-95

Rungtusanatham, M., Forza, C., Koka, B., Salvador, F., Nie, W., 2005. TQM across multiple countries: convergence hypothesis versus national specificity arguments. Journal of Operations Management 23 (1), 43-63.
Sakakibara, S., Flynn, B., Schroeder, R., 1993. A framework and measurement instrument for just-in-time manufacturing. Production and Operations Management 2 (3), 177-194.

Schmenner, R., Swink, M., 1998. On theory in operations management. Journal of Operations Management 17 (1), 97-113.

Schneider, H., Pruett, J., Lagrange, C., 1995. Use of process capability indices in the supplier certification process. Quality Engineering 8 (2), 225-235.

Schroeder, R., Bates, K., Junttila, M., 2002. A resource-based view of manufacturing strategy and the relationship to manufacturing performance. Strategic Management Journal 23 (2), 105-127.

Shah, R., Ward, P., 2003. Lean manufacturing: context, practice bundles, and performance. Journal of Operations Management 21 (2), 129-149.

Shah, R., Ward, P., 2007. Defining and developing measures of lean production. Journal of Operations Management 25 (4), 785-805.

Sila, I., 2007. Examining the effects of contextual factors on TQM and performance through the lens of organizational theories: an empirical study. Journal of Operations Management 25 (1), 83-109.

Sitkin, S., Sutcliffe, K., Schroeder, R., 1994. Distinguishing control from learning in total quality management: a contingency perspective. Academy of Management Review 19 (3), 537-564.

Skinner, W., 1969. Manufacturing-the missing link in corporate strategy. Harvard Business Review 47 (May/June), 136-144.

Skinner, W., 1974. The focused factory. Harvard Business Review 52 (Nov/ Dec), 113-121.

Sousa, R., 2003. Linking quality management to manufacturing strategy: an empirical investigation of customer focus practices. Journal of Operations Management 21 (1), 1-18.

Sousa, R., Voss, C., 2001. Quality management: universal or contextdependent? Production and Operations Management Journal 10 (4), 383-404.

Sousa, R., Voss, C., 2002. Quality management re-visited: a reflective review and agenda for future research. Journal of Operations Management 20 (1), 91-109.

St. John, C., Cannon, A., Pouder, R., 2001. Change drivers in the new millennium: implications for manufacturing strategy research. Journal of Operations Management 19 (2), 143-160.

Thompson, J., 1967. Organizations in Action. McGraw-Hill, New York.

van de Ven, A., Drazin, R., 1985. The concept of fit in contingency theory. In: Cummings, L., Straw, B. (Eds.), Research in Organizational Behavior, 7. JAI Press, Greenwhich, CT, pp. 333-365.

Vastag, G., Whybark, D., 1991. Manufacturing practices: differences that matter. International Journal of Production Economics 23 (1-3), 251259.

Venkatraman, N., 1989. The concept of fit in strategy research: toward verbal and statistical correspondence. Academy of Management Review 14 (3), 423-444.

Venkatraman, N., Prescott, J., 1990. Environment-strategy coalignment: an empirical test of its performance implications. Strategic Management Journal 11 (1), 1-23.

Voss, C., 1995. Alternative paradigms for manufacturing strategy. International Journal of Operations \& Production Management 15 (4), 5-16.

Voss, C., Blackmon, K., 1996. The impact of national and parent company origin on world-class manufacturing: findings from Britain and Germany. International Journal of Operations \& Production Management 16 (11), 98-115

Voss, C., Blackmon, K., 1998. Differences in manufacturing strategy decisions between Japanese and Western manufacturing plants: the role of strategic time orientation. Journal of Operations Management 16 (2/3), 147-158.

Voss, C., Ahlstrom, P., Blackmon, K., 1997. Benchmarking and operational performance: some empirical results. International Journal of Operations \& Production Management 17 (10), 1046-1058.

Voss, C., Blackmon, K., Cagliano, R., Hanson, P., Wilson, F., 1998. Made in Europe: small companies. Business Strategy Review 9 (4), 1-19.

Ward, P., McCreery, L., Ritzman, P., Sharma, D., 1998. Competitive priorities in operations management. Decision Sciences 29 (4), 10351046.

White, R., 1993. An empirical assessment of JIT in US manufacturers. Production and Inventory Management Journal 34 (2), 38-42.

White, G., 1996. A survey and taxonomy of strategy-related performance measures for manufacturing. International Journal of Production \& Operations Management 16 (3), 42-61.

Woodward, J., 1958. Management and Technology. H.M.S.O., London. 